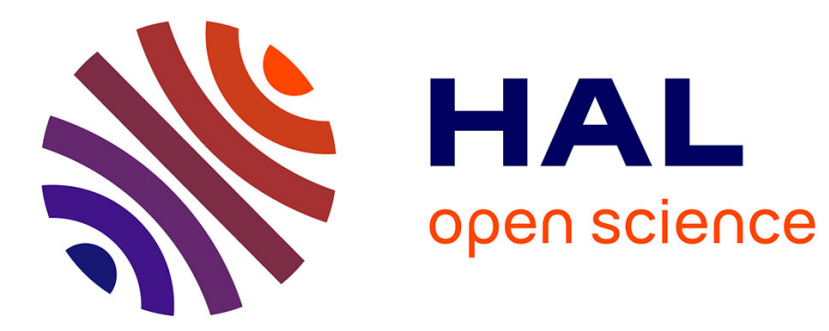

\title{
Electronic shells and supershells in trivalent metal clusters
}

M. Pellarin, B. Baguenard, C. Bordas, J. Lermé, J. Vialle, M. Broyer

\section{To cite this version:}

M. Pellarin, B. Baguenard, C. Bordas, J. Lermé, J. Vialle, et al.. Electronic shells and supershells in trivalent metal clusters. Journal de Physique IV Proceedings, 1994, 04 (C4), pp.C4-714-C4-714. 10.1051/jp4:19944192 . jpa-00252653

\section{HAL Id: jpa-00252653 https://hal.science/jpa-00252653}

Submitted on 1 Jan 1994

HAL is a multi-disciplinary open access archive for the deposit and dissemination of scientific research documents, whether they are published or not. The documents may come from teaching and research institutions in France or abroad, or from public or private research centers.
L'archive ouverte pluridisciplinaire HAL, est destinée au dépôt et à la diffusion de documents scientifiques de niveau recherche, publiés ou non, émanant des établissements d'enseignement et de recherche français ou étrangers, des laboratoires publics ou privés. 


\title{
Electronic shells and supershells in trivalent metal clusters
}

\author{
M. PELLARIN, B. BAGUENARD, C. BORDAS, J. LERMÉ, J.L. VIALLE and M. BROYER
}

Laboratoire de Spectrométrie Ionique et Moléculaire, URA 171 du CNRS, Université Lyon I, Bât. 205, 43 Bd du 11 Novembre 1918, 69622 Villeurbanne cedex, France

Trivalent metal clusters $\left(\mathrm{Al}_{\mathrm{n}}, \mathrm{Ga}_{\mathrm{n}}, \mathrm{In}_{\mathrm{n}}\right)$ are produced in a laser vaporization source. They are photoionized by a tunable UV laser and analysed through a time of flight (TOF) mass spectrometer. The mass spectra are recorded with a photon energy very close to the ionization threshold in order to enhance the relative stability of the clusters. Under these conditions, minima are observed in the mass spectra revealing the most stable clusters. These minima are observed as well for closed electronic shells as for closed atomic shells.

Due to the low melting point of bulk gallium, gallium clusters are liquid-like and roughly spherical. Electronic shells have been observed for the first time [1] in gallium clusters up to 7000 thousand valence electrons (about 2300 atoms). A nice supershell beating structure is observed around 2500 electrons. This number is considerably larger than expected from standard jellium calculations and is consistent with the introduction of a surface softness in the model.

In aluminum, the clusters are more rigid and under usual experimental conditions, they exhibit specific geometric arrangement typical of the octahedral symmetry [2]. However, by heating the source nozzle, we obtain liquid-like aluminum clusters and observe the electronic shell structure up to 1800 electrons.

More experiments are now performed in order to measure these effects at larger sizes, and in particular to observe the second supershell beating structure in gallium clusters expected around 8000 electrons. This observation would confirm our model including the surface softness of the jellium background. These new experimental results will be presented at the conference.

[1] J. Lermé, Ch. Bordas, M. Pellarin, B. Baguenard, J.L. Vialle, and M. Broyer., Phys. Rev. B $\underline{48}$ (1993).

[2] M. Pellarin, B. Baguenard, M. Broyer, J. Lermé, J.L. Vialle, and A. Perez, J. Chem. Phys. 28, 944 (1993). 